\title{
The Beveridge Report and
}

\section{Its Impact on China's Social Security System}

\author{
Yu Zhao \\ School of Manegement, Hebei University, Baoding 071000, China \\ E-mail:zhaoyu365@163.com
}

\begin{abstract}
When it was published on December1st 1942, Social Insurance and Allied Services, or as it was universally called, the Beveridge Report, was an instant and phenomenal success.

It gives the criticism to the England resent social security system. The report pointed that each problem has been dealt with separately, with little or no reference to allied problem. And it causes each kind of social security measure isolation, which sometimes creates repeat, sometimes appears the blank spot.Thus has affected the social security system actual effection. The England social security system reform persists three principles. The first principle is that any proposals for future, while they should use to the full the experience gathered in the past, should not be restricted by consideration of sectional interests established in the obtaining of that experience. The second principle is that ognanization of social insurance should be treated as one part only of a comprehensive policy of social progress. The third principle is that social security must be achieved by co-opration between the state and the individual.The Bverridge Report is one of the most important work which influence the social security system of England and other counties in the world.
\end{abstract}

Keywords: Bveridge report, China's social security, System model, Enlarge coverage, Fund manegement

\section{Intrduction of Bveridge Report}

The main feature of the Plan for Social Security is a scheme of social insurance against interruption and destruction of earning power and for special expenditure arising at birth, marriage or death. The scheme embodies six fundamental principles; flatrate of contribution; unification of administrative responsibility; adequacy of benefit; comprehensiveness; and classification. Based on them and in combination with national assistance and voluntary insurance assubsidiary methods, the aimof the Plan for Social security is to make want under any circumstances unnecessary.It was this promise of comprehensive coverage and adequate benefits that created the vision that after the war, there would be no return to the Bad old days of the Depression and that no-one need ever be poor again. This was the 'rareand refreshing Beveridge' that intoxicated press and public.

The report emphatically elaborated three ways of the social security, social insurance which is the basic needs for the safeguard, national assistant which is special for the guarantee, and voluntary insurance which is demanded outside the basic need. The social insurance is cash allowance refers to the insured provides compulsorily based on pays expenses, it is the most important kind of social securitymeasure, it should comprehensive and universality as far as possible, but it is not the only measure, also needs the national assistant and voluntary insurance as subsidiary methods. The national insurance is the safeguard which provides to the special demand, which is the social security system essential supplement and is free.The voluntary insurance is the supplement to social insurance system and the national assistant system . The purpose of The social insurance and national assistant which is provided by the nation is safeguard one kind of basic survival income, and the different person have different income and the demand existence very big difference, so the goal to provide the high level for the life should be voluntarily insures, and the country should guarantee each measure exsist and encoradge it.

The report pointed out that the England social insurance system development should follow six basic principles: flat rate of subsisstence benefit; flat rate of contribution; unification of administrative responsibility; adequacy of benefit; comprehensiveness; and classification.

Beveridge was adamant that his scheme must be based on the principle Of insurance, as opposed to payments out of general taxation. 'Benefit in return for contributions, ratherthan free allowances from the State, is what the people of Britain desire'. He believed it was wrong in principle to relieve the insured from the burden of contributions so that they'should not feel that income for idleness, however caused, can comefrom a bottomless purse'. This meant that benefits could only be set as high as the poorest members of the community could pay for with their contributions, which meant that while benefits should not be set any lower than was needed for subsistence. They should not be set 
any higher; otherwise the poorest would not be able to afford the contributions. But he wanted benefits to be set atthe minimum level for anotherreason; he believed that the State should not removefrom individuals the will to improve their lot by hardwork and thrift, so he deliberately set the benefits at the minimum to allow individuals to provide for themselves above this if they so wished. Thus he decided that his Plan would be based upon a systemof one flat-rate benefit for everyone who would befinanced by flat-ratecontributions. In deciding this he decided against the schemes, which were common abroad, of relating the benefits and therefore the contributions to the previous earningsof the insured. His insistence on sticking to the insurance principle also meant that he was in some difficulties when it came to retirement pensions. If pensions were paid at the new higher rate immediately then many pensioners would benefit without having made the contributions. He therefore proposed that the full pension should be phased inover a period of twenty years and that inthe meantime only part of the subsistence level benefitwouldbe paid. For millions of pensioners, however, having seen the promised jam, twenty years seemed far too long to wait for it, even if in the case of sound insurance, and this was the one proposal in the Plan which met with general condemnation.

\section{The Enlightenments We Have Gained from Beveridge Report}

\subsection{Which model should we choose for our system}

Before they make a conclusion they firstly make a careful investigation for England's present situation. The suggestions are on basic of the investigation. So in our reform, we should put the investigation on first. Only do like this, our social security system is situable for our country.

At present, the high lever social welfare is not fit for our country. As far as we know, our country is a developing country. And its productive and the industrialization level obviously cannot compared with development country. We should pay proper attention to both fairly with the efficiency social insurance system, simultaneously establishes the perfect costrelatively inexpensive society security system, which is the pattern of "the insurance-rescue". It is because that our country, at present the productive forces level of developmentis not high, and for a long time will occupy the socialism initialstage. At the same time, in view of the fact that the impoverished population scale is bigger in our country city and countryside, and in the quite long time the radical changereality is difficulty, we should gradually establish and consummates the social security system.

Take aged-insurance for example. Internationally there are three major funding models for insurance for the aged: cash basis accounting, full accumulation and partial accumulation. Partial accumulation is actually acombination of cash basis accounting and full accumulation. It achieves across-generation shift in pensions for the aged and are distribution of income, as does cash basis accounting; it also stimulates the payment of premiums and improve sefficiency, as does full accumulation. Partial accumulation reduces the burden of welfare expenditure in cash basis accounting, overcomes the imbalances in individual annual incomes under the full accumulation model, and provides retirees with resources for survival. Partial accumulation has the institutional advantages of full accumulation in terms of accumulating capital and coping with the problems of ageing, yet frees enterprises from the excessive burden of premiums and the problems of preserving and increasing the value of their funds. This model is therefore relatively ideal in China's current situation.

It relieves the pressure brought to bear on capital by the ageing of the population. Expenditure on retirement pensions is currently high in China partly because of the ageing of the population. Cash basis accounting will result in an enormous funding deficit in the approaching ageing crisis. China's Year Book of Statistics (1997) shows that with full accumulation retirement pensions are accounting for an increasingly larger proportion of total salaries. Full accumulation is beyond the capacity of enterprises since workers already bear a heavy burden interms of pensions for the retired, and they can accumulate only very little. There must therefore be a practical way in which we can both provide security for the retired and accumulate capital to deal with the crisis caused by the ageing population. Partial accumulation minimizes the conflict between cash basis accumulation and full accumulation through an appropriate ratio of accumulation. This can keep the ratio of premiums stable without any systemic change.

Partial accumulation will facilitate the goal of a national standard system while recognizing regional differences in terms of security. There are great differences in the economies of different regions in China, which could cause difficulties for a nation-wide system of basic old age insurance. Partial accumulation responds to differences in income and levels of security within an integral system by adjusting minimum premiums and the savings in personal accounts.

Partial accumulation encourages a sense of participation on the part of policy holders. Personal accumulation is determined not only by an individual s salary but also by the premium paid by the enterprise. An employee will therefore actively demand that his or her enterprise buy insurance and pay the premiums regularly. This will widen the coverage of old-age pensions, and encourage enterprises to pay the premiums for their employees.

Partial accumulation is more acceptable to the Chinese who have a tradition of saving. According to a World Bank report, residents' high rate of saving is one of the major factors contributing to rapid economic growth in Southeast Asia. Residents' rate of saving has remained around $40 \%$ of total salary income in China, a much higher rate than the Western 
developed nations and other Asian countries. Saving as a part of the national tradition in China provides a sound foundation for partial accumulation.

Partial accumulation is relatively flexible as an institution. One important difference between full and partial accumulation is that with the latter a greater part of the policy holder's annual premium(basic old-age pension) is still funded by the overall social planning. During periods of high inflation when money loses its value and accumulation alone becomes too little to make any difference, it is even possible to ignore personal accounts and shift to cash basis accounting.

The division of premiums between the overall social planning account and personal accounts for basic medical insurance. Basic medical insurance in china is founded jointly by overal planning and personal accounts.

\section{2 we should enlarge the coverage of social security}

The social security systems also have many gaps and omissions. Current new social security system has not yet comprehensively to be established, China's social security net also has many cracks in fact. National assistant not to be able to consider fully, for example, the housing, the children get sick, the medical service, the child education demand and so on. Some places still have the phenomenon which put "the hypothesized income" and the difficult enterprise staff cannot receive on time to take the real income computation, Which cause part low income resident cannot enter the lowest social security system. Majority rural area also hasn't established the social security system. In social insurance system aspect, there is almost more than half city labors are not be covered by the basic old-age insurance, the system of medical care insurance is only covers less half people; the population of participates in the workers' compensation insurance is cannot contain all. Because of the old-age insurance system's gaps and omissions, the partial old population constituted the new poor which originated in the social welfare system aspect, adapted the senior citizen with the aging of population and the youngest son to nurse system not to mention welfare systems' construction program. The disabled person needs the recovery service also owes to lack. In addition, exceptionally village resident's also face the deficient social security, particularly the peasant the farmer laborer is the main transient population and the scale is huge, but the government consideration has not integrated it The social risks are accumulating continually.

The rural community social security is neglect, it is a big fault of the policy China social security system construction since the country has been reform and open. Therefore, we must protect in countryside resident's weak trend population truly and urge the overwhelming majority countryside resident avoid to degenerate into the minority groups, we also have the necessity to advance the rural community system of social security construction positively. The suggestion urges the city and countryside lowest social security system integration take the village lowest social security system's establishment and as a foundation, take the mutual cooperation constructs as the principle to construct the new village medical service safeguard system, gives birth husbands and wives take the rural planning to construct as the breach the rural society old-age insurance system, concentrates take the countryside household enjoying the five guarantees provides for develops village welfare services gradually as the foundation.

\subsection{How to improve the efficiency of management}

Under government's leadership, makes the corresponding social security laws and regulations through the Legislature, clearify the responsibility of main body all of social security, further consummates the mechanism of the social security responsibility altogether take on.

Must be clearify the government's responsibility. The government's natural responsibility is undertaking protect the minority groups and the leadership entire social security systems. This responsibility is not only manifests in impetus social security aspects 's legislation supervision, and social security movement, moreover direct, manifests specifically in the financial responsibility which the government undertakes. The country must be clear about in finance's social security investment proportion. At the same time, through legislates to be clear about Local authority's social security finance responsibility, abandon the so-called achievements project and the image project, and use the limited financial funds in the promotion employment and protects on the minority groups.

Must be clearify the enterprise's responsibility. The enterprise payment is the important economic basis of social insurance system's. But the present payment rate extremely unfair, and is unbalanced high, which undermine the market economy fair competition environment and harm for the enterprise competitive power. Therefore, in oder to make a clear distinction between the historical responsibility and under the realistic responsibility condition, we should be clear about the limits enterprise's responsibility as soon as possible and realize the enterprise burden equalization rapidly.The new social insurance system should collection social insurance charges to all conform of the legal norm enterprise according to the unified tariff standard, under the control enterprise responsibility's premise, we should enhance the government finance and individual burden proportion according to the social security fund demand.

Must limit the personal liability explicitly. Strengthens the national self-safeguard consciousness and the personal liability, let all the labors share the corresponding social insurance charges is the essential action. First, make a standard of wage statistics category, levies the social insurance charges according to real wages; Second, the expansion social 
security coverage, lets young share the middle and old aged staff's partial responsibilities; third, through consummates measures, personal income tax and interest tax and formulation inheritance tax to adjust the national personal income assignment moderately, let somebody who go the first rich take more responsibility of social security.

While clearify the government, the enterprise and personal liability, the country must guide the community to share the corresponding social security responsibility positively. For example, the government may expand the lottery ticket release and attempt the horse racing and lottery industry safely positively, simultaneously uses the tax preference policy to adjust the enthusiasm which the merit participation charitable public utility from all walks of life contributes. This non-compulsory fund raising way will be able to collect the massive funds, they are the supplement government, the enterprise and individual bear ability directly insufficient important and the beneficial supplement

We should also care about the welfare systems in social administration. Efficiency have been raised repeatedly Western countries. Government socialservice departments are usually over-staffed and overlap, and serious bureaucra-tization has become a scourge in all welfare states. Another reason for low efficiency in social administration is the absence of a clear definition of targets and responsibilities. As early as 1968, the social security reform plan put forward by the American Brookings Institution pointed out that the biggest problem in the American social security system was the attempt to meet two entirely different objectives by means of the same mechan-ism. One objective was to prevent poverty among senior citizens and the other to make sure that pensioners retained a living standard compatible with that before their retirement.' This means that one objective requires universal minimum security, whereas the other makes it necessary for different levels of security to be sought in line with incomes and tax payments. This analysis also applies to other European welfare states. The same mechanism has two different objectives and goals and actions are thus likely to be confused.

\subsection{How to improve the management of fund}

Firstly, the ability of the administrative system to separately manage investment, operations and supervision should be improved.

Secondly, government control over social security funds, particularly old -age pensionfunds, should be gradually relaxed. In the long run, when administration and investment have been separated, and when professional agencies have been established, various channels of investment should be allowed in terms of old-age pensions. It is desirable in China to establish several companies to operate old- age pension funds, and allowing them to invest in stocks and bonds. This will facilitate the development of a mature capital market. The current problem is that the operating companies cannot operate really independently. Even when a company is allowed to operate independently, it is very hard to establish an appropriate supervisory mechanism because of the publicnature of the funds.

Thirdly, there should be an appropriate policy frame work drafted by the central government with regard to enterprise's extra old-age pension payments for the irrespective employees. The funds for these payments should be taken only from the collective welfare funds of enterprises, and enterprises without collective welfare funds should not enjoy additional old-age pensions. At the sametime, there should also be a reasonable and well-managed plan inside enterprises.

Fourthly, the hidden debts of the central government should be liquidated in various ways. The transition costs incurred with regard to old age-pensions for middle-aged and elderly workers should be paid by the central government by transferring stock in state assets. This can be achieved in the following ways: (1)transferring stock in state assets directly to social security departments during the process of incorporation and reform of the joint stock system, and paying the debts with the profits from stock rights; (2)placing some state-owned enterprises under the control of the social security departments and paying the debts with their profits; and,(3)selling or leasing some state-owned assets(such as medium -sized and small enterprises and realestate) and paying the debts with the revenue.

Fifth, the social security overall planning should be reasonably stratified. It was decided in 1998 by the central government that basic old-age pensions should be implemented at the provincial level within three years. The system must be open and cover all members of society.In this sense, provincial overall planning serves only as an intermediate stage.

At present the scope of overall planning for medical insurance should be determined according to regional economic development. Regions with higher levels of urbanization and economic development should setup a system based on municipal overall planning with the support of provincial risk funds, while less urbanized regions with an under-developed economy should initially place greate remphasis at a county level. Large enterprises should also be all owed to setup their own medical insurance companies.

Sixth, legislation on the social security system should be speeded up. We should evolve an integrated scheme through experimentation, and regularize this scheme by incorporating it into StateCouncil documents. Adjustments and revisions should be allowed during the implementation process. Legislation with regard to medical insurances hould be undertaken gradually according to the difficulty of each programandits progress. The first step is to determine specific regulations, and on this basis develop social security laws to p rovide a legal framework. 


\section{Conclusion}

Constructs the harmonious society, the most basic is to establish a perfect social security. Party's 17th conference proposed that we must speed up the establishment of social security system. It is not only the important attribute to maintains the social stability, but also a important attribute to promotion economic development.

Beveridge Reporte is designed by Knight Beveridge. Its background is 60 years ago, Britain is being in "the most brutal, the most comprehensive, the most essential" time of war. In order to unite the British nationals to cross the difficult time, Knight Beveridge has designed the one whole set the social security systems for Britain "from the cradle to the grave", which is called the blueprint of welfare state.

Accroding to operating practice, Beveridge Rport is the prologue of welfare state construction, which has profound influence to the postwar capitalism world's social structure reconstruction and the transform functions of the government. Beveridge Rport is holding the indisputable immortal status in the social security history. It initiates the idea, the principle, the method and even established the welfare systems frame has the profound influence to social security's development. After the it is published more than 60 years, it is quoted by the innumerable people, studies, imitates. It is a milestone-like document in development of the human race history.

After the reform and open policy our country has adopted the non-balanced developmental strategy. Including: Gives priority to the economy; First individual local development and so on. This strategy while is promoting national economy development enormously, also has created a series of negative consequences. And the most serious consequence is, was not all people shares the achievement of reform and open policy, which performanced by the income differential and the local disparity expanded day by day.

Although our country present is entirely different from Britain's macroscopic environment before 60 years, but it is urgently need to eliminate these negative consequences under the construction harmonious society's background. And Beveridge Reported has provided some beneficial mentalities for us.

These mentalities include: First, social security systems' basic goal is guaranteed that each citizen will not fall into the life difficult position in any situation. What Beveridge stressed repeatedly is "lets the most difficult person spend on the normal life", but does not guarantee "on life in plenty" - - the latter to depend upon individual market diligently the strength. This is not only embarks from person's primary need, but also embarks from the national economical carrying capacity.

Second, the embarrassment of economy and the pecuniary is not the reason of postponing social security systems construction. Because social security systems solution is for the most difficult person, avoids this question take the financial problem as the excuse, not humanity.

Third, the social security systems plan need a Coordination committee which is inter-departmental to complete. Beveridge believed that social security systems' construction is a engineering systems, involves society's aspects, also involves the special benefit of various society group's. Therefore, it is unable to imagine without a such Coordination committee to advance construction of the system.

To promote the economical and society's accord development well, our country should begin from the below aspect to establish the reasonable social security system: Expands the coverage of social security, raises the social security fund in the multi-road, forms the joint effort of individual, collective and government; to promotes the specialization of employment service and the socialization. In social security system's construction, we must both enable social security system to play a full function but also must avoid harmful of the high safeguarding to the economic efficiency. finally we had better to achieve the unification of both personally fair and the social justice and realize individual efficiency and social efficiency balanced.

\section{References}

Bveridge. (1942).Social Insurance and Allied Services(the Beveridge Report).

Charles Madge. (1943).Industry after the War London.P35.

Howard Gelennerster. (1995). British Social Policy since 1945. Blackwell.P25.

Information Office of the State Council of the People's Republic of China. (2004).China's Social Security and Its Policy.

John Brown. (1995).The British Welfare State.In A Critical History. Blackwell. P26

Jose Harris. (1990).Enterprise and Welfare State. a Comparative Perspective. In Transactions of the Royal Historical Society. pp181-184.

W.J.Mommsen. (1981).The Emergency of the Welfare State in Britain and Germany. London. p297. 